\title{
Development and characterization of a fibroblastic-like cell line from caudal fin of the red-line torpedo, Puntius denisonii (Day) (Teleostei: Cyprinidae)
}

\author{
Thangaraj R Swaminathan ${ }^{1}$, Wazir S Lakra ${ }^{2 *}$, Achamveettil Gopalakrishnan ${ }^{1}$, Valaparambil S \\ Basheer $^{1}$, Basdeo Kushwaha ${ }^{2}$ \& Kavungal A Sajeela ${ }^{1}$ \\ ${ }^{1}$ National Bureau of Fish Genetic Resources Cochin Unit, CMFRI Campus, Kochi, Kerala, India \\ ${ }^{2}$ National Bureau of Fish Genetic Resources, Lucknow, Uttar Pradesh, India
}

Correspondence: T R Swaminathan, National Bureau of Fish Genetic Resources Cochin Unit, CMFRI Campus, PO Box 1603, Kochi 682018, Kerala, India. E-mail: rajathanga@yahoo.co.in

*Present address: W S Lakra, Central Institute of Fisheries Education, Fisheries Road, Seven Bungalows, Andheri west, Mumbai 400061 , India.

\begin{abstract}
A fibroblastic-like cell line was established from the ornamental fish, red-line torpedo (Puntius denisonii). The red-line torpedo fin (RTF) cell line is being maintained in Leibovitz's L-15 medium supplemented with $10 \%$ fetal bovine serum (FBS) for over 1 year at $28{ }^{\circ} \mathrm{C}$ on a continuous basis in normal atmosphere. The growth rate of RTF cells increased as the FBS proportion increased from $5 \%$ to $20 \%$ at $28{ }^{\circ} \mathrm{C}$ with optimum growth at the concentrations of $10 \%$ FBS. The morphology of RTF cell was predominantly fibroblastic like. Propagation of these cell lines was serum dependent, with a low plating efficiency $(<15 \%)$. Karyotyping analysis of RTF cells at the 25 th passage indicated that the modal chromosome number was $2 n=50$. The cell line was cryopreserved in liquid nitrogen at $-196{ }^{\circ} \mathrm{C}$ and could be recovered from storage after 6 months with good cell viability. Polymerase chain reaction amplification of a fragment of two mitochondrial genes, 16S rRNA and $\mathrm{CO1}$, confirmed the identity of these cell lines with those reported from this animal species, confirming that the cell lines originated from $P$. denisonii. The bacterial extracellular products from Vibrio cholerae MTCC3904 and Aeromonas hydrophila were found to be toxic to RTF. The cell lines were not susceptible to viral nervous necrosis virus, a marine fish virus.
\end{abstract}

Keywords: Puntius denisonii, red-line torpedo, cell line, RTF

\section{Introduction}

Red-line torpedo, Puntius denisonii (Day) (Family Cyprinidae), is one of important freshwater ornamental fish endemic to the Western Ghats Biodiversity hotspot. The species is in high demand in both domestic and international markets and being exploited from the wild in large quantities and exported (Anna Mercy, Gopalakrishnan, Kapoor \& Lakra 2007). Presently, $P$. denisonii is the most preferred ornamental fish from this region in the international trade and it fetches retail prices between US\$20 and US\$30 (http://www.aquahobby.com/gallery/e_Puntius_denisonii.php). In India, it is commonly known as both 'Miss Kerala' and 'Chora Kanni' (literally 'bleeding eyes'). Recent reports of successful captive breeding of much sought after species like the red-line torpedo is likely to revolutionize the ornamental fish industry in India (http://www.fishesninverts.com/?p=168).

The growth of ornamental industry in India has also been accompanied by an increased awareness of the adverse impact of diseases, particularly those caused by pathogenic viruses. It is mandatory for the exporting countries to certify that every consignment of ornamental fish is in good health and free from OIE (World Organization for Animal Health) for listed diseases, which is mostly caused by viruses (OIE Code 2009). Fish cell lines are also found to be essential for isolation and identification of viruses that provoke epizootic outbreaks, causing economic losses in the fish culture systems (Bols 1991). The 
establishment of permissive cell lines from host animals is essential for the isolation, identification and study of pathogenic viruses. Wolf and Quimby (1962) developed the first cell line from the gonad tissue of rainbow trout. Thereafter, at least $\sim 283$ fish cell lines have been established from bony fish (Lakra, Swaminathan \& Joy 2011), but only few of them are readily available from international cell culture repositories such as American Type Culture Collection (ATCC) or European Collection of Cell Cultures (ECACC) for scientific research. In India, majority of the work is based on primary cell culture but not on continuous cell lines, except recent works published (Hameed, Parameswaran, Shukla, Singh,Thirunavukkarasu \& Bhonde 2006; Lakra, Bhonde, Sivakumar \& Ayyappan 2006; Ahmed, Chandra, Sudhakaran, Rajesh Kumar, Sarathi, Sarath Babu, Ramesh \& Sahul Hameed 2009; Lakra, Swaminathan, Rathore, Goswami, Yadav \& Kapoor 2010; Swaminathan, Lakra, Gopalakrishnan, Basheer, Khushwaha \& Sajeela 2010). Currently, there is no cell line available from $P$. denisonii. The purpose of the present study was to establish a cell line from this fish species that has very high demand in the international ornamental fish market. The cells were evaluated for optimal growth conditions, their stability in liquid nitrogen, karyotyping and susceptibility to bacterial extracellular products (ECP). This newly established cell line will enhance the current attempts in establishing effective diagnostic methods for detecting and monitoring viral infection in this important ornamental species.

\section{Materials and methods}

\section{Preparation of tissues for primary cell cultures}

Juvenile fish (ranging $5-8 \mathrm{~cm}$ in total length) were collected from the Valapattanam River, Iritty, Kannur District, Kerala, India, and transported live to the laboratory. They were acclimatized in the laboratory for 2 weeks. The sterilization of surface of the fish was carried out by wiping the fish in $80 \%$ (v/v) ethanol. The fish was anaesthetized using $2 \mathrm{~mL}$ of the clove oil solution [nine parts ethanol $(94 \%)+$ one part clove oil] into $5 \mathrm{~L}$ of water. Tissues such as heart, caudal fin and swim bladder were collected from the fish using sterile instruments and aseptic techniques and each tissue was processed individually. Containers were surface-disinfected with betadine (10\% povidone iodine) and all processes were carried out in a laminar flow cabinet. Tissues were washed four times in phosphate buffer saline (PBS)-containing antibiotics $\left(500 \mathrm{IU} \mathrm{mL}^{-1}\right.$ penicillin, $500 \mu \mathrm{g} \mathrm{mL}^{-1}$ streptomycin and $2.5 \mu \mathrm{g} \mathrm{mL}^{-1}$ fungizone) before preparing explants.

\section{Tissue explants}

The tissues were minced in $10 \mathrm{~mL}$ PBS using two scalpel blades until a suspension of small tissue fragments was obtained. Each tissue suspension was then aspirated into a $10 \mathrm{~mL}$ pipette, placed in a $50 \mathrm{~mL}$ tube and centrifuged at $100 \mathrm{~g}$ for $5 \mathrm{~min}$ at $4{ }^{\circ} \mathrm{C}$. The supernatant of each tissue was removed and the pellet was resuspended in $6 \mathrm{~mL}$ PBS. The tissue fragments were placed into $25 \mathrm{~cm}^{2}$ cell culture flasks with fetal bovine serum (FBS) for attachment of explants and kept overnight at $28^{\circ} \mathrm{C}$. After ensuring the attachment of the explants, $7 \mathrm{~mL}$ of complete growth medium (Leibovitz's L-15 supplemented with $20 \% \mathrm{FBS}$ ), antibiotics (penicillin, $100 \mathrm{IU} \mathrm{mL}^{-1}$, streptomycin, $\left.100 \mu \mathrm{g} \mathrm{mL}^{-1}\right)$ and fungizone $\left(2.5 \mu \mathrm{g} \mathrm{mL}^{-1}\right)$ was added slowly. The flasks were incubated at $28^{\circ} \mathrm{C}$ in a normal atmosphere incubator and left undisturbed to allow optimum cell attachment before examination by light microscopy. Half of the medium was changed every week. Nikon TE2000-S (Nikon, Tokyo, Japan) equipped with phase optics was used to observe and photograph living cell cultures every 2-3 days for primary cell cultures and subcultures.

\section{Subculture, maintenance, storage and revival}

When a confluent monolayer was formed in the primary culture, the cells were washed with calciumand magnesium-free PBS (CMF-PBS) three times and the cells were harvested with $0.25 \%$ trypsinEDTA solution. The cells were subcultured at 1:2 to 1:3 ratios and maintained in the complete L-15 medium with $20 \% \mathrm{FBS}, 200 \mathrm{IU} \mathrm{mL}^{-1}$ penicillin, $200 \mu \mathrm{g} \mathrm{mL}^{-1}$ streptomycin and $0.5 \mathrm{\mu g} \mathrm{mL}^{-1}$ amphotericin B. After the 10th subculture, the concentration of FBS in medium was reduced to $10 \%$ (L-15-10), and antibiotics and antimycotics were reduced to the normal concentrations of $100 \mathrm{IU} \mathrm{mL}^{-1}$ penicillin, $100 \mu \mathrm{g} \mathrm{mL}^{-1}$ streptomycin and $0.25 \mu \mathrm{g} \mathrm{mL}^{-1}$ amphotericin B. The subcultures were stored in the liquid nitrogen $\left(-196^{\circ} \mathrm{C}\right)$ in the freezing medium, which consisted of L-15 plus $50 \%$ FBS and $10 \%$ dimethyl sulphoxide. Briefly, cells with $80 \%$ confluency were harvested as described earlier. These cells were resuspended to $2 \times 10^{6}$ cells $\mathrm{mL}^{-1}$ and aliquoted to 
cryovials ( $1.5 \mathrm{~mL}$ cell suspension). The cryovials were kept at $-20{ }^{\circ} \mathrm{C}$ for $2 \mathrm{~h}$, at $-70{ }^{\circ} \mathrm{C}$ overnight and then transferred to liquid nitrogen containers $\left(-196^{\circ} \mathrm{C}\right)$. For revivals, a cryovial was thawed quickly in water bath at $37^{\circ} \mathrm{C}$ and centrifuged at $200 \mathrm{~g}$ for $5 \mathrm{~min}$ at room temperature. The cells were resuspended with L-15 medium supplemented with $10 \% \mathrm{FBS}, 100 \mathrm{IU} \mathrm{mL}^{-1}$ penicillin, $100 \mathrm{\mu g} \mathrm{mL}^{-1}$ streptomycin and $0.25 \mu \mathrm{g} \mathrm{mL}^{-1}$ amphotericin $\mathrm{B}$, and seeded in a $25 \mathrm{~cm}^{2}$ tissue culture flask. The viability of the revival cells was estimated by trypan blue staining and the cells were counted on a haemocytometer.

\section{Effect of temperature and FBS on cell growth}

To examine the effect of temperature and varied concentrations of FBS on red-line torpedo fin (RTF) cell growth, the cells at the concentration of $5 \times 10^{4}$ were inoculated into $25 \mathrm{~cm}^{2}$ cell culture flasks and incubated at $28{ }^{\circ} \mathrm{C}$ for $2 \mathrm{~h}$. The batches of culture flasks were then incubated at selected temperatures of $20,26,28,30$ and $37^{\circ} \mathrm{C}$. Temperature experiments were performed using normal growing medium supplemented with $20 \%$ FBS. Every other day, duplicate flasks at each temperature regime were washed with CMF-PBS twice, after which $0.2 \mathrm{~mL}$ of $0.25 \%$ trypsin solution was added to each flask. When the cells rounded up, the cell density was measured microscopically by using a haemocytometer. The experiment was carried out for 5 days. The experiments were conducted in triplicates. The cells were grown in different concentrations of FBS $(5 \%, 7.5 \%, 10 \%, 15 \%$ and $20 \%$ ) using the same procedure as mentioned above at $28{ }^{\circ} \mathrm{C}$.

\section{Effects of sera on cell growth}

The effect of FBS, newborn calf serum (NBCS) and mixture of FBS and NBCS at $10 \%$ on the growth of RTF cells was tested. Briefly, cultures just attaining confluence were trypsinized with $0 \cdot 1 \%$ trypsin and $0 \cdot 01 \%$ EDTA in CMF-PBS. Cells were suspended in the standard medium containing $10 \%$ FBS, and then plated in $25 \mathrm{~cm}^{2}$ flask at a density of $5 \times 10^{5}$ cells. After overnight culture (day 1 ), the medium was replaced by one of the three kinds of media that contained either $10 \%$ FBS, $10 \%$ NBCS or $5 \%$ NBCS serum plus 5\% FBS. The cultures were trypsinized and the number of cells was counted with a haemocytometer three times per flask after 5 days of incu- bation at $28^{\circ} \mathrm{C}$. Three flasks were measured for each of the experimental media (10\% FBS, $10 \%$ NBCS serum and 5\% NBCS serum plus 5\% FBS). The media of cultures were changed every 2 days.

\section{Plating efficiency (PE)}

Plating efficiency of RTF cells was tested at the 10th passage. Cells were diluted in growth medium and seeded in $25 \mathrm{~cm}^{2}$ flasks at densities of 200,500 and 1000 cells in triplicate. Red-line torpedo fin cell line was incubated at $28{ }^{\circ} \mathrm{C}$ for 14 days. The resulting clones were fixed with a solution containing $25 \%$ formalin, $10 \%$ ethanol (95\%) and 5\% acetic acid. Plating efficiency was estimated by staining with a $1 \%$ crystal violet solution in a formalin fixative. Individual cell colonies were counted using a microscope. Plating efficiencies were calculated using the formula: $\mathrm{PE}$ $(\%)=$ number of cell colonies/number of cells seeded $\times 100$ (Freshney 2005).

\section{Chromosomal analysis}

Standard procedure as described by Freshney (2005) with some modification was followed. Briefly, RTF cells at the 25 th passage were incubated in a $25 \mathrm{~cm}^{2}$ tissue culture flasks until $80 \%$ confluence at $28^{\circ} \mathrm{C}$. Colchicine solution (Invitrogen, Grand Island, NY, USA) was added to the cells at a final concentration of $0.2 \mu \mathrm{g} \mathrm{mL}^{-1}$ and then the cells were incubated overnight at $28{ }^{\circ} \mathrm{C}$. After gentle pipetting, detached cells were collected by centrifugation at $200 \mathrm{~g}$ for $5 \mathrm{~min}$ at $4{ }^{\circ} \mathrm{C}$, treated with a hypotonic solution of $0.65 \% \mathrm{KCl}$ for $20 \mathrm{~min}$ and fixed in 1:3 of acetic acid:methanol for $5 \mathrm{~min}$ at room temperature. The fixed cells were collected by centrifugation at $200 \mathrm{~g}$ for $5 \mathrm{~min}$ at $4{ }^{\circ} \mathrm{C}$ and resuspended in fixative solution. The cell suspension was dropped onto a clean slide glass. After air dry, 5\% Giemsa solution was added for $20 \mathrm{~min}$ at room temperature to stain chromosomes and 100 cells at metaphase were counted under a light microscope.

\section{Viral susceptibility and cytopathic effect (CPE)}

Viral nervous necrosis virus (VNNV)-infected RTPCR-positive tissue samples (the only virus reported from India) of Asian sea bass Lates calcarifer were collected from hatcheries in Nagapattinam of Tamilna$\mathrm{du}$, India. The virus was isolated from the infected tissues by homogenizing them in L-15 medium with 
antibiotics and without FBS. The homogenate was frozen and thawed three times before centrifuging at $13000 \mathrm{~g}$ for $1 \mathrm{~h}$ at $4{ }^{\circ} \mathrm{C}$ and the supernatant was filtered by a $0.22 \mu \mathrm{m}$ membrane and inoculated into RTF cells. After $1 \mathrm{~h}$ of adsorption at room temperature, the supernatant was discarded, and the cells were washed with phosphate buffer three times. Following this, L-15 medium with 5\% FBS was added to the cells and incubated at $30^{\circ} \mathrm{C}$ and the cells were examined daily for the occurrence of CPE for 10 days. To ensure the viability of VNNV in the tissue homogenate, the disease was reproduced in the juveniles of the Asian sea bass by exposing them to the filtrate of the infected tissue homogenate in a biosecure area.

\section{Cytotoxicity test of bacterial ECPs}

The cytotoxicity of bacterial ECP from Vibrio cholerae MTCC 3904 (strain type that was readily available in our laboratory) and Aeromonas hydrophila (isolated and characterized in our laboratory) to RTF cells was tested. The cellophane plate technique of Liu (1957) was used. Briefly, sterilized cellophane sheets were placed on the surface of Brain Heart Infusion Agar (Himedia Laboratories, Mumbai, India) plates and inoculated by spreading $0.5 \mathrm{~mL}$ of a $24 \mathrm{~h}$ old broth culture of $V$. cholerae with a sterile swab and incubated at $37^{\circ} \mathrm{C}$. After incubation for $48 \mathrm{~h}$, cells were washed off the cellophane with a minimum volume of PBS. All the cell suspensions were centrifuged at $10000 \mathrm{~g}$ for $30 \mathrm{~min}$ at $4{ }^{\circ} \mathrm{C}$. The supernatants were filtered through a $0.22 \mu \mathrm{m}$ pore size membrane (Millipore, Billerica, MA, USA), freeze-dried and reconstituted in PBS to a final volume of $10 \mathrm{~mL}$. All ECP samples were stored at $-30{ }^{\circ} \mathrm{C}$ until use. The cells were grown as a monolayer in 24-well plates at $28^{\circ} \mathrm{C}$ using L-15 medium supplemented with $5 \%$ FBS. For the toxicity test, the cell line was inoculated with $0.1 \mathrm{~mL}$ serial dilutions of ECP. For negative controls, plates were inoculated with sterile saline. Plates were incubated at $28{ }^{\circ} \mathrm{C}$ and the effects of ECP on the cells were observed after $12 \mathrm{~h}$ for 3 days.

\section{PCR for confirmation of origin of $P$. denisonii cell lines}

The origin of the RTF cell line was authenticated by partial amplification and sequencing of 16S rRNA and $\mathrm{CO} 1$ regions of the $P$. denisonii. Briefly, the samples were homogenized separately in NTE buffer (0.2 m NaCl, 0.02 m Tris-HCl, 0.02 m EDTA, pH 7.4) and centrifuged at $3000 \mathrm{~g}$ at $4{ }^{\circ} \mathrm{C}$, after which the supernatant fluids were placed in fresh centrifuge tubes together with an appropriate amount of digestion buffer (100 mM NaCl, $10 \mathrm{mM}$ Tris-HCl, pH 8.0, 50 mM EDTA, pH 8.0, 0.5\% sodium dodecyl sulphate, $0.1 \mathrm{mg} \mathrm{mL}^{-1}$, proteinase $\mathrm{K}$ ). After incubation at $65^{\circ} \mathrm{C}$ for $2 \mathrm{~h}$, the digests were deproteinized by successive phenol/chloroform/isoamyl alcohol extraction and DNA was recovered by ethanol precipitation, drying and resuspension in TE buffer. The primer pair sequences of the 16S rRNA and CO1 are given in Table 4. PCR was carried out in a Vetri ${ }^{\mathrm{TM}}$ 96-well thermal cycler (Applied Biosystems, Foster City, CA, USA). Each PCR reaction was in a $25 \mu \mathrm{L}$ volume containing both forward and reverse primers $(10 \mu \mathrm{m}, 0.5 \mu \mathrm{L}$ each), $\mathrm{MgCl}_{2}(25 \mathrm{mM}, 1.5 \mu \mathrm{L})$, dNTPs $(2 \mathrm{mM}, 2.0 \mu \mathrm{L})$, PCR buffer $(10 \times, 2.5 \mu \mathrm{L})$, Taq DNA polymerase $(1 \mathrm{U}$, $0.5 \mu \mathrm{L})$, template DNA $(0.3-0.4 \mu \mathrm{g})$ and nucleic-acidfree water. PCR cycling conditions included an initial denaturation at $95^{\circ} \mathrm{C}$ for $5 \mathrm{~min}$, followed by 30 cycles of $95{ }^{\circ} \mathrm{C}$ for $45 \mathrm{~s}$, annealing temperature of $50^{\circ} \mathrm{C}$ for $30 \mathrm{~s}, 72{ }^{\circ} \mathrm{C}$ for $45 \mathrm{~s}$ and a final extension of $5 \mathrm{~min}$ at $72{ }^{\circ} \mathrm{C}$. The PCR products were visualized on $1.2 \%$ agarose gels and the amplified products were selected for sequencing. The cleaned up PCR products were sequenced in Applied Biosystems AB 3730 XL capillary sequencer following the manufacturer's instructions at the sequencing facility. The raw DNA sequences were aligned against known sequences from the National Center for Biotechnology Information (NCBI) database and edited using BIOEDIT sequence alignment editor version 7.0.5.2.

\section{Result}

Cell cultures were initiated from several tissues of $P$. denisonii including heart, swim bladder and caudal fin tissues. The cells migrated from the different tissue fragments and grew well and formed a monolayer during the first month. Out of three selected tissues/ organs, we were able to establish one cell line from caudal fin (Table 1). Emergence of growing cells from swim bladder and heart occurred 25 and 22 days after the explantation of minced tissue fragments respectively. The swim bladder and heart cells consisted of epithelial-like and long fibroblastic-like cells respectively (Fig. 1e and f). However, these swim bladder and heart cells showed a poor survivability and died following subcultivation. We could not maintain the heart and swim bladder cells after the 12th and the 11th passage respectively. However, the cells from 
Table 1 Details of the cell line development from the different tissues of Puntius denisonii

\begin{tabular}{lrrr}
\hline & \multicolumn{2}{c}{ P. denisonii } \\
\cline { 2 - 5 } Details (number of explants/cell line) & \multicolumn{3}{c}{ Swim } \\
\cline { 2 - 5 } Number of explants & 20 & 40 & 15 \\
Contamination of the explant & 3 & 28 & 8 \\
No radiation of the explant & 10 & 4 & 3 \\
Radiation of the explant & 7 & 8 & 4 \\
Formation of monolayer & 2 & 5 & 2 \\
Contamination of the monolayer & 0 & 2 & 0 \\
Number of cultures capable of subculturing & $2^{*}$ & $3 \dagger$ & $1 \ddagger$ \\
Number of cultures still being cultured & 0 & $1 \S$ & 0 \\
\hline
\end{tabular}

* One of the two cell lines could not be subcultured after the 12th passage and the other after the 10th passage.

$\dagger$ Two cell lines could not be subcultured after the 10th passage. $\ddagger$ Cell line could not be subcultured after the 11th passage. $\S$ Current passage level is 52 . the caudal fin grew continuously. In the initial passages, fin cells were composed of a heterogeneous mixture of fibroblastic-like and epithelial-like cells (Fig. 1d). After 15 subcultures, fin cells were predominantly fibroblastic-like cells (Fig. $1 \mathrm{~g}-\mathrm{i}$ ). The different morphological characteristics of the cell lines developed from the different tissues of the $P$. denisonii are given in Table 2. In primary culture, fin cells adhered well and achieved confluence in 6 days at $28^{\circ} \mathrm{C}$. Cells were subcultured in L-15 medium with $20 \%$ FBS every $4-5$ days for the initial 10 passages. For the first 15 passages, $50 \%$ culture medium was replaced with fresh medium at 4-day interval. After 15 th subcultures, cells were subcultured at a ratio of 1:3 at 3-4day interval, and FBS was reduced to $15 \%$ in the L-15 culture medium. The fin cells were being subcultured more than 52 times since initiation and are designated as an RTF cell line.
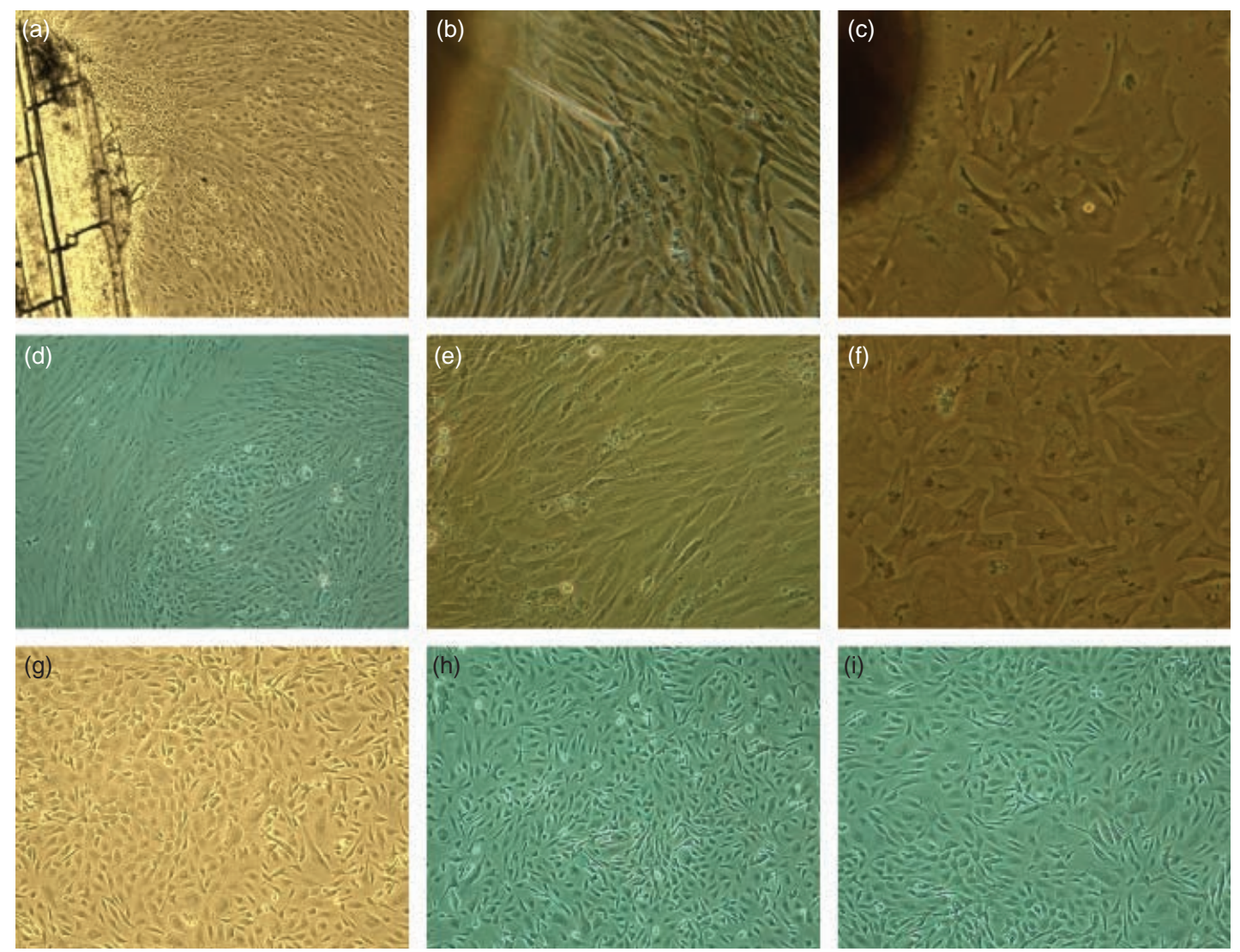

Figure 1 Photomicrographs of Puntius denisonii cells derived from different tissues. (a) Fin explant showing radiation of cells $(100 \times)$; (b) heart explant showing radiation of cells $(200 \times)$; (c) swim bladder explants showing radiation of cells $(200 \times)$; (d) heterogeneous populations of both epithelial-like and fibroblastic-like cells of fin cells $(100 \times)$; (e) monolayer of heart cells at the eighth passage $(200 \times)$; (f) monolayer of swim bladder cells at the 10 th passage $(200 \times)$; $(\mathrm{g})$ monolayer of RTF cells at the fifth passage $(100 \times)$; (h) monolayer of RTF cells at the 20 th passage $(100 \times)$; and (i) monolayer of revived RTF cells 6 months after cryopreservation $(100 \times)$. RTF, red-line torpedo fin. 
Optimal growth temperature for RTF cells ranged 26-30 ${ }^{\circ} \mathrm{C}$. However, maximum growth was obtained at $28^{\circ} \mathrm{C}$ (Fig. 2a). Red-line torpedo fin cells were also able to spread and grow well at $20^{\circ} \mathrm{C}$, although it took $48 \mathrm{~h}$ for the cells to become well attached (Fig. 2d). When incubated at $30{ }^{\circ} \mathrm{C}$, the cells proliferated fast during the first $48 \mathrm{~h}$, but the growth and prolif-

Table 2 Morphological characteristics of the cell lines established from Puntius denisonii

\begin{tabular}{lll}
\hline Tissue source & Initial growth & Morphology \\
\hline Caudal fin & ++++ & Fibroblastic like \\
Swim bladder & +++ & Epithelial like \\
Heart & ++ & Long fibroblastic like \\
\hline
\end{tabular}

++++ , rapid growth and formed over $75 \%$ cell monolayer; +++ , extensive outgrowth and formed large-size cell colonies; ++ , outgrowth with small-size colonies surrounding tissue explants. eration slowed dramatically, and the cells appeared to age rapidly (Fig. 2e). Although cells remained viable during the test period when incubated at $37^{\circ} \mathrm{C}$, cell growth was minimal and individual cells looked abnormal (Fig. 2f). The growth rate of RTF cells increased as the FBS proportion increased from $2 \%$ to $20 \%$ at $28{ }^{\circ} \mathrm{C}$. Cells exhibited poor growth at $5 \%$ concentrations of FBS, relatively good growth at $10 \%$ but maximum growth occurred with the concentrations of $15 \%$ and $20 \%$ FBS.

The details of the formation of the monolayer of RTF cells at varying concentrations of FBS, NBCS and equal mixture of FBS and NBCS has been given in Table 2. Red-line torpedo fin cells in early passage changed shape depending on the kind of sera with which they were treated. The number of cells increased at a steady rate in each medium during the culture period. The cells in FBS-supplemented medium were typically fibroblastic like, and sharply
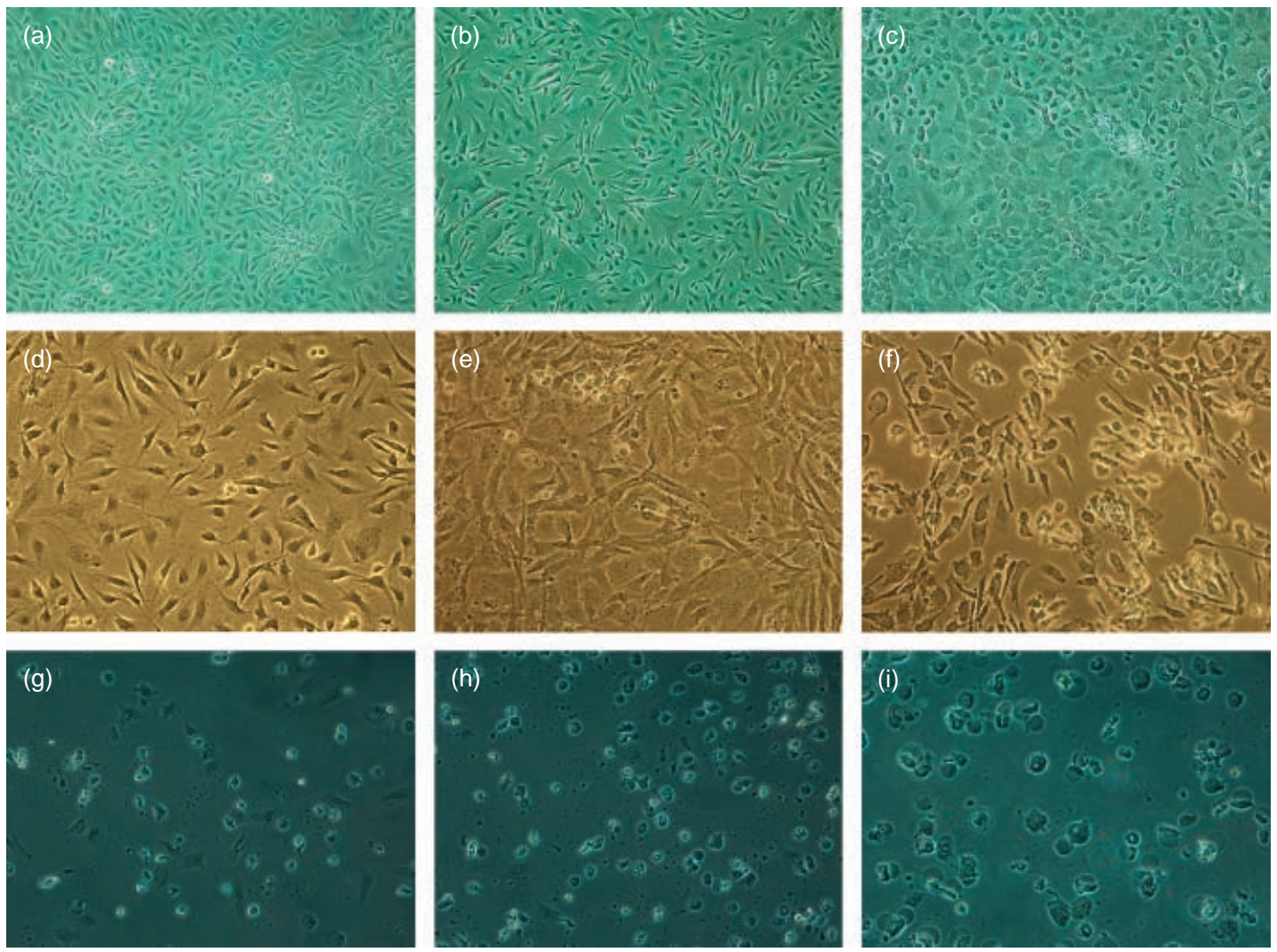

Figure 2 Red-line torpedo fin (RTF) cellular morphology at different animal serum, growing temperatures and cytotoxic effects of ECP of Vibrio cholerae MTCC 3904. (a) Red-line torpedo fin cells at $28^{\circ} \mathrm{C}$ and $10 \% \mathrm{FBS}(100 \times)$; (b) RTF cells at $28^{\circ} \mathrm{C}$ and $5 \%$ NBCS and $5 \%$ FBS $(100 \times)$; (c) RTF cells at $28^{\circ} \mathrm{C}$ and $10 \%$ NBCS $(100 \times)$; (d) RTF cells at $20^{\circ} \mathrm{C}(100 \times)$; (e) RTF cells at $30^{\circ} \mathrm{C}(100 \times)$; (f) RTF cells at $37^{\circ} \mathrm{C}(100 \times)$; (g) RTF cells at 1-day post-inoculation of $V$. cholerae MTCC 3904 ECP; (h) RTF cells at 2-day post-inoculation; and (i) RTF cells at 3-day post-inoculation. FBS, fetal bovine serum; ECP, extracellular products; NBCS, newborn calf serum. 
outlined (Fig. 2a). The morphology of the cells in NBCS and FBS-supplemented medium was as same as in the earlier case with slight change in their health status (Fig. 2b). In the presence of NBCS alone, the cells were epithelial like and less clearly outlined, extending dendritically (Fig. 2c). Plating efficiency of RTF cell line was determined at seeding concentrations of 200, 500 and 1000 cells. Moderately low PEs were observed with RTF cells $[10.5( \pm 0.5) \%, 13.07$ $( \pm 2.53) \%$ and $14.37( \pm 5.66) \%]$ respectively.

The RTF cells were cryopreserved at the 10th, 20th and 30th passages. The cells were recovered after 6 months from storage and grew to confluency within 5 days (Fig. 3). The average viability of the cells after cryopreservation was estimated to be $80 \%$ with the same morphology. The diploid karyotype of RTF cells is shown in Fig. $4 \mathrm{a}$ and consists of 25 pairs of telocentric $(2 n=50)$ chromosomes. The results of chromosome counts of 100 metaphase plates from RTF cells at passage 25 revealed that in the $32 \%$ of the cells, the chromosome number varied from 38 to 54 (Fig. 4b) and about $68 \%$ of the cells had a diploid chromosome number of $2 n=50$.

The RTF cells were resistant to the marine VNNV. No CPE was observed in the cells up to 2 weeks of observation and even after 10 blind passages. The ECPs

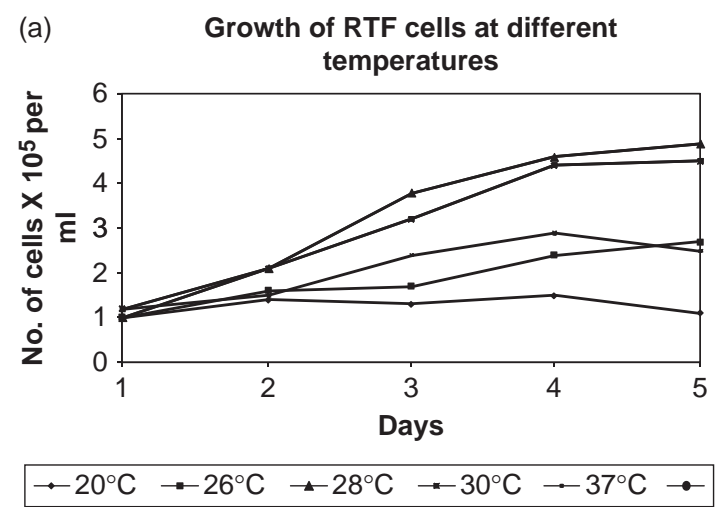

from $V$. cholerae MTCC 3904 and A. hydrophila (data not shown as the strain was not procured from any referral culture collection centres) proved to be cytotoxic for all RTF cell lines. Cytotoxic effects could be observed within $10 \mathrm{~h}$ after inoculation. The morphological changes detected in these cell lines were rounding, detaching and finally monolayer destruction (Fig. $2 \mathrm{~g}-\mathrm{i}$ ). To verify the origin of RTF cell line, DNA was isolated from the RTF cells at their 25th passage. Amplification and sequencing of the $16 \mathrm{~S}$ rRNA and COI genes from the RTF cell lines and P. denisonii muscle tissue revealed 562 and 642 bp edited sequences (Fig. 5) in all samples. Subsequent comparative analysis of the identified sequences revealed a $100 \%$ match for RTF and P. denisonii muscle tissue, as well as a $99 \%$ match to known P. denisonii mitochondrial DNA sequences in the GenBank at NCBI. These sequences have been submitted to GenBank (COI accession number-GU566029) (Tables 3 and 4).

\section{Discussion}

The main purpose of this study was to establish new cell line that has not been reported in this ornamental fish. Although the attempt was aimed at establish-



Figure 3 Growth response of the RTF cell line to (a) selected temperature and (b) selected fetal bovine serum (FBS) concentrations.

Figure 4 Chromosome analysis of RTF cells. (a) Karyotype of RTF cells (passage 25) indicates all 24 pairs of telocentric chromosomes. (b) Metaphase chromosome numbers of RTF cells at passage 25. RTF, red-line torpedo fin. (a)

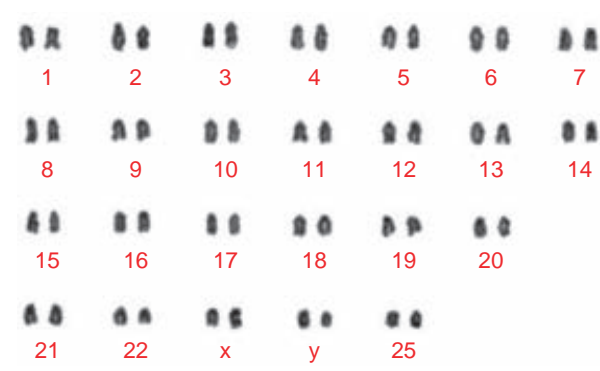

(b)

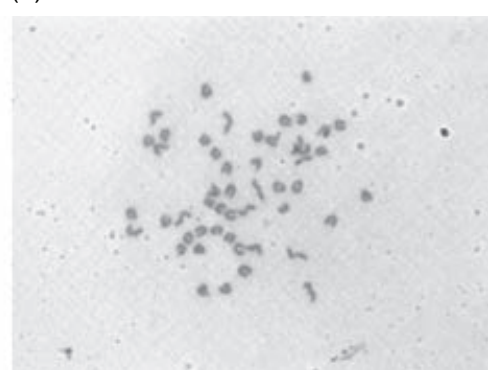






Table 4 List of mtDNA primers

\begin{tabular}{llllll}
\hline $\begin{array}{l}\text { Serial } \\
\text { number }\end{array}$ & Primers & & Sequence $\mathbf{5}^{\prime} \mathbf{- 3}^{\prime}$ & $\begin{array}{l}\text { Number of } \\
\text { bases }\end{array}$ & Reference \\
\hline 1. & 16S rRNA & L & CGCCTGTTTATCAAAAACAT & 20 & Palumbi, Martin, Romano, McMillan, \\
& & H & CCGGTCTGAACTCAGATCACGT & 22 & Stice and Grabowski (1991) \\
2. & COI & F & TCAACCAACCACAAAGACATTGGCAC & 26 & Ward, Zemlak, Innes, Last and Hebert (2005) \\
& & R & TAGACTTCTGGGTGGCCAAAGAATCA & 26 & \\
& & R & TAGACTTCTGGGTGGCAAAGAATCA & 26 & \\
\hline
\end{tabular}

ing primary cell culture from multiple tissues and organs including heart, swim bladder and caudal fin, we were able to establish a cell line from caudal fin (RTF) only. The RTF cells were passaged up to 52 passages in vitro and no morphologic alternation was noticed. All of the cultured RTF cells were harvested when they reached $90 \%$ confluence. Too many passages and excess trypsin digestion could adversely affect the biological characteristics of cells, especially the hereditary characteristics; hence, we restricted the passages of RTF cells up to 52. The morphological results indicated that there were both epithelial-like cells and fibroblastic-like cells present during the pri- mary and the early passages of the RTF cells. Different tolerances to trypsin were evident as the fibroblasts fell off first when treated with trypsin and were adherent again quickly after passage, while most epithelial cells were not adherent or stably adherent and fell off only when treated with mechanical agitation (Ren, Li \& Zhang 2002). This could be a possible reason for the homogenous population of fibroblastic like in the RTF cells after 15 passages.

As observed in other established fish cell lines, the growth of RTF cells was temperature dependent. The growth temperature range for RTF was $26-30{ }^{\circ} \mathrm{C}$ with optimum growth at $28{ }^{\circ} \mathrm{C}$, which was identical 
with other fish cell lines reported previously (Kang, Oh, Kim, Kawai \& Jung 2003; Ahmed et al. 2009; Ku, Teng, Wang \& Lu 2009). The growth of RTF cells at $10 \%$ concentration of FBS was relatively good and which is an advantage to maintain this cell line at low cost.

Newborn calf serum alone or in combination with FBS had growth-promoting effects on fin cells in early passage and was effective as same as FBS on cell growth. The complementary effects of the combined use of NBCS and FBS might be due to some factors that are present or abundant in NBCS but not in FBS and vice versa. In this study, we observed morphologic changes in fin cells in early passage especially in the presence of NBCS. The findings are in corroboration with the earlier findings in goldfish fin cells when carp serum was used in combination with FBS (Hashimoto, Toyohara, Yokoyama, Sakaguchi, Ozato \& Wakamatsu 1997). Newborn calf serum may contain the factor(s) that are responsible for the alteration of the normal cell shape of RTF cells. Our research implies that NBCS in combination with FBS was effective for investigations of fish cell growth especially in utilizing primary culture cells.

The PE data suggested that the cell lines performed better when seeded at a relatively higher density. Cryopreservation of cell lines is necessary for longterm storage. The feasibility of cryopreservation of this cell line was demonstrated, with appreciable recovery 6 months after thawing of up to $80 \%$. The viability of different cell lines was demonstrated that all the cells have the ability to survive following storage at $-196{ }^{\circ} \mathrm{C}$ by various workers (WSF, WSBM and WSHST cells - Wang, LaPatra, Zeng, Zhao \& Lu 2003; SISK - Hameed et al. 2006; LCF and LCE - Lakra et al. 2006; RE and CB cells - Ahmed et al. 2009). Partial sequence information of $16 \mathrm{~S}$ rRNA (562 bp) and COI (642 bp) was used to further confirm the origin of the newly established RTF by PCR. The amplified PCR fragment was sequenced and this DNA fragment was determined to match perfectly with the genomic sequence of $16 \mathrm{~S}$ rRNA and COI reported previously for $P$. denisonii. The mitochondrial 16S rRNA, 12S rRNA and COI gene sequence alignment has been used as reliable molecular method to accurately identify the origin of cell lines of many fish species such as rohu (Ahmed et al. 2009), grouper (Ku et al. 2009). The sequence data confirmed that the newly established cell lines were derived from $P$. denisonii. Red-line torpedo fin cells at passage 25 were used to determine the chromosome number. Our finding of the same peak range of chromosomes in this cell line at their early passage in vitro suggests that the P. denisonii (diploid) karyotype has 50 chromosomes $(2 n=50)$. Future study by using G-banding or other karyotyping techniques would be necessary and important to determine the modal chromosomal number of this species and the host origin of established RTF cell lines as well. Our results are consistent with the published literature, suggesting that the cell lines were obtained from P. denisonii (Nagpure, Kumar, Srivastava, Gopalakrishnan, Verma \& Basheer 2005).

The ECP from V. cholerae MTCC 3904 and A. hydrophila were cytotoxic to the RTF cell line. Many fish cells have proven suitable for demonstrating the cytotoxic effects of pathogenic bacteria including V. cholerae (Swaminathan et al. 2010), and members of the various genera (Ahmed et al. 2009; Ku et al. 2009). Thus, RTF are ideal for testing the cytotoxic factors of fish vibriosis and Aeromonas infection. The susceptibility of cell lines to viral infection is the basis for isolating and characterizing fish viruses. Viruses affecting cyprinids have not been isolated in India so far and the only fish virus reported from the country was VNNV (isolated from a perciform fish), which was tested on the RTF cell line, but found not susceptible. Viruses are obligatory intracellular parasites and their in vitro replication generally requires permissive cell lines and derived from the same host species (Lu, Nerurkar, Aguirre, Work, Balazs \& Yanagihara 1999). The RTF cell lines may be used for isolation of viruses in disease outbreaks in cyprinids, especially in Puntius species.

Although the RTF cells remained viable following liquid nitrogen storage, their $\mathrm{PE}$ was rather low $(<15 \%)$. Because general characteristics for transformed cell cultures include serum-independent growth, high contact inhibition and high PE (Freshney 2005), our findings suggest that RTF cells were not transformed in the passages for which they were tested. The non-transformation status of these cell line was further evidenced by their chromosomal typing, showing a diploid chromosomal count of 50 in majority (68\%) of cells, which has been documented in the literature for this aquatic species (Nagpure et al. 2005).

Puntius denisonii is the most sought after freshwater ornamental fish from Indian waters (Anna Mercy et al. 2007). In the view of the reports of the recent success in development of breeding techniques (http://www.fishesninverts.com/?p=168) and recent initiatives to promote ornamental fish culture in India (Silas, Gopalakrishnan, Anna Mercy, Sarkar, Pushpangadhan, Kumar \& Anikuttan 2010) taken up 
by the Marine Products Exporting Development Authority (MPEDA), Ministry of Commerce and Industry, Government of India, the ornamental fish industry in India is expected to expand vigorously. This may be hampered by many factors including diseases, especially those caused by viruses. All countries exporting ornamental fish are in the compulsion to certify that their native fish population is free of the OIE-listed diseases for the safe transboundary movement of live aquatic animals. Some pathogenic viruses are known to be organ and tissue specific, which makes the establishment of additional cell lines from different organs and tissues of a host species essential for proper monitoring of viral diseases (Luc Rougée, Ostrander \& Richmond 2007). In the absence of susceptible cell culture systems, other methods and techniques, such as electron microscopy and bioassays, may be relied upon for the diagnosis of viruses that are expensive and not as easily reproducible as in vitro cell cultures. Hence, the development of RTF cell line would be valuable for isolation of the virus in any disease outbreaks in P. denisonii and also for studying species-specific responses of the viruses at the cellular level.

In conclusion, a freshwater fish cell line, RTF, was established from fin of $P$. denisonii that was subcultured more than 52 passages and diploid at their present passages. The cell line can be used for developing cell models for toxicological and genotoxicological studies to replace whole animals and for genetic engineering. Further, we plan to carryout research on the newly established RTF cell line regarding their biological properties and functions, so that the cell lines can be made available to scientists all over the world for the advancement of in vitro research in aquatic science.

\section{Acknowledgment}

The authors are thankful to Dr S. Ayyappan, Director General, ICAR, New Delhi, India, for the encouragement and guidance.

\section{References}

Ahmed V.P.I., Chandra V., Sudhakaran R., Rajesh Kumar S., Sarathi M., Sarath Babu V., Ramesh B. \& Sahul Hameed A.S. (2009) Development and characterization of cell lines derived from rohu, Labeo rohita (Hamilton), and catla, Catla catla (Hamilton). Journal of Fish Diseases 32, 211-218.
Anna Mercy T.V., Gopalakrishnan A., Kapoor D. \& Lakra W.S. (2007) Ornamental Fishes of Western Ghats, India. NBFGR Publication, Lucknow, India, 235pp.

Bols N.C. (1991) Biotechnology and aquaculture: the role of cell cultures. BiotechnologyAdvances 9, 31-49.

Freshney R.I. (2005) Culture of Animal Cells - A Manual of Basic Techniques. Wiley-Liss, New York, NY, USA, 641pp.

Hameed A.S.S., Parameswaran V., Shukla R., Singh I.B., Thirunavukkarasu A.R. \& Bhonde R.R. (2006) Establishment and characterization of India's first marine fish cell line from kidney of sea bass; Lates calcarifer. Aquaculture 257, 92-103.

Hashimoto H., Toyohara H., Yokoyama Y., Sakaguchi M., Ozato K. \& Wakamatsu Y. (1997) Effects of carp serum on the growth of goldfish fin cells in early passage. Journal of Fish Biology 50, 201-207.

Kang M.S., Oh M.J., Kim Y.J., Kawai K. \& Jung S.J. (2003) Establishment and characterization of two cell lines derived from flounder; Paralichthys olivaceus (Temminck \& Schlegel). Journal of Fish Diseases 26, 657-665.

Ku C.C., Teng Y.C., Wang C.S. \& Lu C.H. (2009) Establishment and characterization of three cell lines derived from the rockfish grouper Epinephelus quoyanus: use for transgenic studies and cytotoxicity testing. Aquaculture 294, 147-151.

Lakra W.S., Bhonde R.R., Sivakumar N. \& Ayyappan S. (2006) A new fibroblast like cell line from the fry of golden mahseer Tor putitora (Ham). Aquaculture 253, 238-243.

Lakra W.S., Swaminathan T.R. \& Joy K.P. (2011) Development, characterization, conservation and storage of fish cell lines: a review. Fish Physiology and Biochemistry 37, $1-20$.

Lakra W.S., Swaminathan T.R., Rathore G., Goswami M., Yadav K. \& Kapoor S. (2010) Development and characterization of three new diploid cell lines from Labeo rohita (Ham). Biotechnology Progress 26, 1008-1013.

Liu P.V. (1957) Survey of haemolysin production among species of Pseudomonas. Journal of Bacteriology $\mathbf{7 4}$, 718-727.

Lu Y., Nerurkar V.R., Aguirre A.A., Work T.M., Balazs G.H. \& Yanagihara R. (1999) Establishment and characterization of 13 cell lines from a green turtle (Chelonia mydas) with fibropapillomas. In Vitro Cellular and Developmental Biology-Animal 35, 389-393.

Luc Rougée G.K., Ostrander R.H. \& Richmond Y.L. (2007) Establishment, characterization, and viral susceptibility of two cell lines derived from goldfish Carassius auratus muscle and swim bladder. Diseases of Aquatic Organisms 77, 127-135.

Nagpure N.S., Kumar R., Srivastava S.K., Gopalakrishnan A., Verma M.S. \& Basheer V.S. (2005) Cytogenetic studies of fish species Horabagrus nigricollaris, Puntius denisonii and Puntius subnasutus endemic to the Western Ghats. The Nucleus 47, 143-148.

OIE Code. (2009) Aquatic Animal Health Code. OIE - World Organization for Animal Health, Paris. 
Palumbi S., Martin A., Romano S., McMillan W.O., Stice L. \& Grabowski G. (1991) The Simple Fool's Guide to PCR. University of Hawaii, Honolulu, HI, USA.

Ren F.L., Li Y. \& ZhangY. (2002) In vitro cultivation and freezing of bovine skin fibroblast cells. Journal of Yellow Cattle Science 1, 8-10.

Silas E.G., Gopalakrishnan A., Anna Mercy T.V., Sarkar K., Pushpangadhan K.R., Kumar P.A. \& Anikuttan K.K. (2010) Guidelines for Green Certification of Ornamental Fish - Report of the Task force. Marine Products Export Development Authority (MPEDA), Ministry of Commerce \& Industry, Govt. of India, Kochi, Kerala, India, 86pp.

Swaminathan T.R., Lakra W.S., Gopalakrishnan A., Basheer V.S., Khushwaha B. \& Sajeela K.A. (2010) Development and characterization of a new epithelial cell line PSF from caudal fin of Green chromide, Etroplus suratensis (Bloch, 1790). InVitro Cellular and Developmental Biology - Animal 46, 647-656.

Wang G., LaPatra S., Zeng L., Zhao Z. \& Lu Y. (2003) Establishment, growth, cryopreservation and species of origin identification of three cell lines from white sturgeon, Acipenser transmontanus. Methods in Cell Science 25, 211-220.

Ward R.D., Zemlak T.S., Innes B.H., Last P.R. \& Hebert P.D.N. (2005) DNA barcoding Australia's fish species. PhilosophicalTransactions of the Royal Society of London. Series B; Biological Sciences 360, 1847-1857.

Wolf K. \& Quimby M.C. (1962) Established eurythermic line of fish cells in vitro. Science 135, 1065-1066. 